\title{
Negotiation Techniques in the Diplomacy of the Roman Empire to the Hun Empire During Attila Period
}

\section{Zexu Han}

$24^{\text {th }}$ Middle School of Shijiazhuang, 050051

Email: vetotashann@gmail.com

Abstract: The diplomacy of the Roman Empire is usually regarded as the appendage of the Roman military, but its diplomacy after the decline of the Roman military is seldom studied. The arguments presented here analyze the diplomatic negotiation skills of the Roman Empire during the Attila period, that is, the negotiation skills of the Romans when the Roman army lost its power.

Keywords: Roman Empire、Negotiation techniques、Attila、 diplomacy、Huns

\section{Introduction}

After Attila ascended the throne, he united all the tribes of the Hun empire with muscular approaches, and the huge empire that formed made Rome feel great pressure. In order to deal with this situation, the envoys sent by Theodosius II met with Attila ${ }^{[1]}$. Priscus witnessed these diplomacies as a companion and provided many details. By analyzing these details, we may be able to understand the situation at that time.

British diplomat Nicholson even wrote in his book: "The Romans did not have any special talent in the technical aspects of negotiation. For centuries they ruled, their way was to train the army and build roads, not diplomats." But at that time, the Roman Empire had no strength to carry out a large-scale war. The original city-state and military town structure were disintegrated, which seriously damaged the social foundation of the Roman Empire. Roman emperors had to increase their ranks of officials and try to collect taxes in broken areas. But the increased administrative costs, in turn, further weaken the level of support the army can have. In this case, the Romans had to maintain a brief peace through diplomatic means.

\section{Negotiation techniques in the diplomacy of the Roman Empire}

\subsection{The background of the Roman Empire and Hun Empire at Attila period}

Fragments 10 (pp. 241-243), from the Excerpta de Legationibus. 4:

When the treaXty was in force, Attila again sent envoys to the eastern Romans demanding the fugitives. They received the envoys, honoured them with many gifts and sent them away saying that they had no fugitives.

Fragments 11.2 (pp. 277-279), from the Excerpta de Legationibus. 3:

When we express amazement at the unreasonableness of the barbarian, Romulus, an ambassador of long experience, replied that his very great good fortune and the power which it had given him [Attila] had made him so arrogant that he would not entertain just proposals unless he thought that they were to his advantage.

These fragments show the change of foreign policy of the Hun Empire to the Roman Empire. At that time, the Huns had found that the Roman army in the 5th century A.D. had not always been the victorious division in the 1ST-2ND century, and the increasingly powerful Hun Empire had the strength to fight against the Roman Empire. They began to Copyright (C) 2020 Zexu Han doi: $10.18282 /$ le.v9i5.1202

This is an open-access article distributed under the terms of the Creative Commons Attribution Non-Commercial License (http://creativecommons.org/licenses/by-nc/4.0/), which permits unrestricted non-commercial use, distribution, and reproduction in any medium, provided the original work is properly cited. 
seek more resources and lands, also launched many small-scale raids in the East and west of the Roman Empire ${ }^{[2]}$. The strength of the Hun Empire shocked Rome, but at that time Rome was not willing to face the Hun army directly, but the prudence and concession shown by Rome made the Huns more ambitious. In Priscus' record, he made it clear that Attila was no longer satisfied with his achievements, but began to seek more interests ${ }^{[3]}$. But the Roman army was not strong enough to stop, in this case, the Romans were eager to reach a peace treaty, although they had to pay more interests. The disintegration of the original city-state and military town structure caused serious damage to the social foundation of the Roman Empire. Roman emperors had to increase their ranks of officials and try to collect taxes in broken areas. But the increased administrative costs, in turn, further weaken the level of support the army can have. As a result, the Romans could only expand into a large group of small-scale regiments to the level of thousands of people, which were arranged to be garrisoned in various local towns. These so-called Army soldiers, in addition to guarding the local areas, are difficult to make a difference in foreign wars. They often fight each other to make the Empire's defense more fragmented. At that time, the slavery system of the Western Roman Empire was on the verge of collapse ${ }^{[4]}$. The slave movement of Bagaudae made the Western Roman Empire unable to resist the Huns, so it could only make diplomatic peace.

\subsection{The Roman's diplomacies before the fall of the Roman Empire}

As early as in the reign of the king, the rudiments of international law began to appear in the fichiaris law ${ }^{[4]}$. At that time, there was a legal system for the declaration of war and peace.

The legitimate reasons for the war are:

(1) the invasion of Roman territory

(2) the invasion of ambassador

(3) the violation of treaty

(4) the assistance of friendly countries to enemy countries in the war ${ }^{[5]}$

In ancient Rome, the declaration of war required extremely complicated procedures. The priests of fitchiaris had to go several times to destroy the city of international decision ${ }^{[6]}$. And every time they hold ceremonies, chant incantations and curse the destroyers of international law. Then the priests returned to Rome, waiting for an answer for 33 days ${ }^{[6]}$. In the absence of an answer, the priest fichiaris reported to the Senate and citizens who had the right to declare war. After that, the father, the representative of the priesthood of fitchiaris, went to the border of the enemy's city and threw a spear with a hot head and blood stained on the enemy's land ${ }^{[7]}$.

To end the war, Rome also had legal rules:

(1) the two sides concluded a peace treaty to terminate the war

(2) the enemy surrendered to terminate the war. In this case, the enemy's life and property can be preserved

(3) conquer the enemy country and end the war. In this case, the enemy's life and property can be disposed of freely

Although Roman diplomatic law is a very humanitarian law, during the period of Roman expansion, the Romans only used these laws to find the excuse of war, relying on the powerful army to maintain its diplomacy but did not play the role of diplomacy. However, when the Roman army lost its control over the surrounding states and tribes, the diplomatic strategy played a huge role in maintaining the peace of the Roman Empire ${ }^{[6]}$.

\subsection{The diplomatic negotiation techniques of the Romans in the records of priscus}

Analyze the negotiation techniques of Rome through the diplomatic situation between Romans and Persians in the records of priscus.

Fragments 41.1 (pp. 345-347), from the Excerpta de Legationibus . 15:

[After an embassy arrived from Italy in Constantinople]. An embassy also arrived from the Persian monarch which complained to the Romans both about the Persians who were fleeing to the Romans and about the Magi who had lived from old in Roman territory. The embassy alleged that the Romans, wishing to turn the Magi from their ancestral customs, laws and forms of worship, harassed them and did not allow the fire, which they call unquenchable, to be kept burning according to their law. It also said that the Romans, through a contribution of money, should show interest in the fortress of Iouroeipaach, situated at the Caspian gates, or they should at least send soldiers to guard it. It was not right that the Persians alone should be burdened by the expense and the garrisoning of the place, since if they did 
not make these expenditures, the neighbouring peoples would easily inflict damage not only upon the Persians but upon the Romans also. The Romans replied that they would send someone to discuss all these issued with the Parthian monarch. They claimed that there were no fugitives amongst them and that the Magi were not harassed on account of their religion, and said that since the Persians had undertaken the guarding of the fortress of Iouroeipaach and the war against the Huns on their own behalf, it was not right that the demand money from the Romans. Constantius... was sent to the Persians.

Because of the rise of the Hun Empire, the relationship between the Romans and the Persians began to ease. From the word "complained", it shows that the Romans and the Persians gave up military confrontation temporarily, and sent ambassadors to each other's countries to show the same situation ${ }^{[8]}$. Moreover, the Persians wanted Rome to bear some of the guards and the costs of the fortresses. At this time, the Romans avoided these problems with their skillful negotiation techniques (the Romans explained the religion, customs, and other issues related to Magi in detail, but they were very tough in the face of donation ${ }^{[9]}$. The reason why Rome did this was that they knew that Persia was more afraid of the Hun empire than Roman. On the other hand, because of the strength of Rome in the past and its suzerain status, Attila did not want to fight against Rome in an all-round way. The common Catholic identity in Europe makes them hate the Sassanian people. The Hun empire's attack on Persia can get more support from many European tribes, and will not make the Hun Empire besieged by the surrounding countries and tribes ${ }^{[10]}$. The Romans made good use of this point. In the situation of the decline of the military power of the Roman Empire, the diplomacy of the Romans became more skillful and more difficult to refute. Although Roman diplomatic law is a very humanitarian law, during the period of Roman expansion, the Romans only used these laws to find the excuse of war, relying on the powerful army to maintain its diplomacy but did not play the role of diplomacy ${ }^{[10]}$.

Fragments 47 (pp. 353-355), from the Excerpta de Legationibus 19:

When the Romans replied that each had to fight for his own land and take care of his own defence, the again returned having achieved nothing.

During the negotiation, the Romans saw that Persia was worried about the attack of Saraguri, so when Persia asked for money from Rome on this issue, Rome showed great composure and rejected the Persian's request with undisputed theory.

Fragments 11.2 (pp. 277-279), from the Excerpta de Legationibus. 3:

And so... he would subdue the Medes, the Parthians, and the Persians and force them to pay tribute.

When we prayed that he would go against the Persians and direct the war against them, Constantiolus said that he feared that when he had easily subdued the Persians, he would return as a master rather than a friend.

After he listed the parts of Iran Attila could conquer, he prayed that Attila would destroy the Sasanians, but only then included a report of a companion saying that if Attila destroyed the Sasanians, he would be more powerful than the Romans and would no longer be there equal. Thus the Romans would have a larger problem on their hands.

Another manner in which Priscus portrays the Sasanians is how he demonstrates the efforts of the Sasanians to get the Romans to guard the Caspian Gates against Hunnic incursions ${ }^{[14]}$. The Sasanians, according to Priscus, felt they kept the Huns at bay, and had the job of protecting both the empire of the Iranians and the Roman Empire.

While negotiating with Persia, the Romans were still diplomatic with the Huns, and they hoped Attila would lead his army to attack tribes in Iran. This kind of large-scale diplomacy seldom took place before, and this kind of negotiation skill caused the Romans to shift the target of Hun Empire and Sassanian Empire and made the two countries start to fight, while the Roman Empire cleverly avoided this large-scale war and avoided huge war losses ${ }^{[9]}$. Although it only procrastinated some time, it can still be said that it was an exemplary diplomatic strategy.

\subsection{Diplomacy between Rome and its vassal states}

For two years after the battle of Strasbourg, Julian signed peace agreements with Alemanni's leaders on the other side of the Rhine. At the same time, the co-emperor Constantius II also made peace agreements with various tribes in the middle of the Danube River. As mentioned above, these peace treaties were presented to the Roman people in the same way: the barbarians surrendered completely [called "deditio" in Latin] ${ }^{[15]}$, then Rome was merciful and generous, and they were able to enter into a peace treaty [called "Federation" in Latin] so that they became subjects 
of the Empire. However, the degree of forced submission and the actual content of the agreement vary from tribe to tribe. In 357, when Constantius was in the middle of the Danube, the Romans were in complete control. In this case, Rome is likely to interfere in the political structure of its opponents, abolish the alliances that seem too dangerous in the long-term interests of Rome, and promote the subordinate leaders who obey to take power independently. These and Yori included Roman recruitment from barbarians and sometimes required them to provide more troops for specific campaigns. From 357 to 358 A.D., Emperor Urian also asked the Alemannian to compensate them for their losses ${ }^{[12]}$. Like this time, this kind of compensation is often in the form of food supply, but if they cannot compensate for food, they have to provide labor and construction timber and pay for freight. It is also a common practice to submit hostages, for example, atanaric's father is a hostage. Sometimes it works. A little leader of Alemanni contacted the religion in the Mediterranean area in Rome and was deeply touched. After returning, he renamed his son Serapio according to the Egyptian god Serapis ${ }^{[15]}$. When the Romans did not have full control of the situation, they asked the barbarians to provide labor, raw materials, and troops, and approved the political structure that had developed independently. In any case, across the border from Rome are the numerous Vassal States dominated mainly by the Germanic people, which are indeed part of the Roman world

On the whole, the relationship between Rome and the vassal states across the European border in the 4th century A.D. is hardly consistent with the traditional relationship between the barbarians and Rome in their ideas. At all levels, both sides enjoy mutually beneficial relations even if they are not equal. Vassal states had trade relations with the Empire, provided recruits for the army of the Empire, and were regularly influenced by the Empire's diplomatic intervention and culture $^{[16]}$. On the other hand, they can get aid from the Empire every year, at least sometimes, with a certain degree of respect. One of the notable features of the peace agreement is that it is usually formalized according to the norms of the vassal states and Rome. Even if the political elites of the Empire had to pretend to the taxpayers that the Germans had not made any progress, they were far from the "other" as the Romans imagined. In recent years, people have realized more and more clear that this new order in the diplomatic relations between the Romans and the Germans is based on a series of far-reaching changes in Germanic society.

\subsection{The Battle of the Catalaunian Plains}

In 449 A.D., the sister of the emperor of the Western Roman Empire, Honoria, was found to have an affair with the chief bodyguard, and the emperor Valentine put her under house arrest in a monastery ${ }^{[17]}$. Aurelia secretly wrote to Attila to ask for help, claiming that she was willing to commit herself. Attila immediately asked Valentine, the emperor of Western Rome, for anolia, and when she was refused, she set out to invade Gaul ${ }^{[18]}$.

All the barbarians in the Western Roman Empire were shocked by the devastation of the northern part of Gaul. They all realized that they could not fight against the Huns by their own strength. Ejus seized this opportunity to fight against the Huns, ran around, and exerted his superb political ability to build a united front against the Huns ${ }^{[19]}$. The Germanic barbarians from Gaul and all over Spain, even the Celtic tribes of Britain, sent troops to help; the old enemy who had fought with ejus for 20 years, Theodoric, the king of Visigoth, also led the troops to help.

\section{Conclusion}

In fact, in Rome's heyday, its negotiating techniques were overshadowed by its military might. When it gradually weakened, its military power was not enough to maintain its rule. At this time, its negotiation skills gradually emerged. It was a turning point in the fifth century A.D., after which the Roman Empire began to lose the seniority of equal diplomacy. When the Roman Empire negotiated with the Hun Empire led by Attila, it can be considered that the Roman Empire exerted its negotiation skills to the extreme.

\section{References}

1. Warren Treadgold. The Early Byzantine Historians[M]. Palgrave Macmillan, 2010.

2. Barnard H , Rose P J . Eastern Desert Ware from Berenike and Kab Marfu'a[M]// Berenike 1999/2000. 2007.

3. Blue L . Locating the Harbour: Myos Hormos/Quseir al - Qadim: a Roman and Islamic Port on the Red Sea Coast of 
Egypt[J]. International Journal of Nautical Archaeology, 2007, 36.

4. Malden, R. H . The Foundations of the Roman Empire[J]. Greece \& Rome, 1946, 15(43):1-6.

5. EdwardGibbon. The history of the decline and fall of the Roman empire[M]. Liaoning People's Publishing House, 2016.

6. Bradley K R. Slaves and masters in the Roman Empire : a study in social control / K. R. Bradley[J]. The American Historical Review, 1986, 91(1).

7. Werner Eck. Diplomacy As Part Of The Administrative Process In The Roman Empire[M]// Diplomats and Diplomacy in the Roman World. Brill, 2008.

8. Cary M. The Roman Empire[J]. classical review, 1930, 44(2):78-79.

9. By H. Stuart Jones. The Roman Empire, B.C. 29-A.D. 476[J]. american journal of education, 1908(10).

10. Kelly, Nigel, Rees, Rosemary, Shuter, Jane. The Roman Empire[J]. politics, 2006.

11. Scham, and S. "Diplomacy and desired pasts.” Journal of Social Archaeology 9.2(2009):163-199.

12. Madeleine H . Rome and the Roman empire[J]. Antiquity, 2006, 80(310):372-1035.

13. B. Wilkinson. The Roman Empire by M. P. Charlesworth (review)[J]. canadian historical review, 1951, 32.

14. Michael Maas. The Cambridge Companion to the Age of Attila: Chronology[J]. english historical review, 2006, 121(492):págs. 823-825.

15. Maenchen-Helfen R B O . A History of Attila and the Hunsby E. A. Thompson[J]. American Historical Review, 1949, 55(1):110-112.

16. Rankov Boris. Roman Military Equipment[J]. antiquity, 2004, 44(1):256-138.

17. A.H.M. Jones. Battle of the Catalaunian Plains[C]// International Conference on Environmental \& Computer Science. IEEE, 2009.

18. Frederic P. Miller, Agnes F. Vandome, John McBrewster,etc. Campaign History of the Roman Military[M]. Alphascript Publishing, 2011.

19. Whately C . Jordanes, the Battle of the Catalaunian Plains, and Constantinople[J]. Dialogues Dhistoire Ancienne, 2013, S 8(Supplément 8):págs. 65-78. 